\title{
Pesquisa no Brasil?
}

\author{
Research in Brazil, are there?
}

Dentre as grandes questర̋es com que, hoje em dia, se vêem a braços os países do Terceiro Mundo, ocupa lugar prioritário a feição competitiva que lhes é imposta em nível intemacional. Em tal panorama de extrema concorrência, a pesquisa científica ocupa lugar de relevo. Constitui questão aberta a incapacidade desses, eufemisticamente denominados de "países em desenvolvimento", como o nosso, de estabelecer política científica que pudesse desembocar em realizações tecnologicas próprias e sem peias, internas ou externas. Observa-se perene desistímulo à pesquisa básica, como a ignorar os frutos que poderiam ser colhidos com os seus investimentos. $E$ isso em termos das necessidades populacionais e do proprio mercado.

Tais reflexōes vêm à mente com a leitura de entrevista publicada em semanário de grande penetraçăo em nosso meio (Cesar $\left.{ }^{2}, 1995\right)$. Nela estampa-se a falta de orientaçāo do governo, no que concerne à pesquisa no país. Na opinião do pesquisador entrevistado, nenhum país deveria renunciar à pesquisa básica, sob pena de "... se colocar no nível de colônia", transformando-se em nação de "apertadores de botôes das máquinas vendidas pelos grandes centros do conhecimento." Essa é a questão que me parece fundamental. Não há como fugir, ou investe-se nessa etapa da pesquisa ou condena-se o país a ser sempre apenas um "país em desenvolvimento". Posiciono-me pois, inteiramente de acordo com aquele ponto de vista.

O Brasil, com 150 milhőes de habitantes e 8,5 milhōes de quilômetros quadrados, não pode ser encarado como sendo o eterno "país do futuro". A sua populaçāo tem necessidades a serem atendidas para atingir qualidade de vida compatível com seu significado mundial. Penso que, neste ponto, seria adequado exemplificar com os programas de Pesquisa e Desenvolvimento Tecnológico (RDT) lançados pela Comunidade Européia, desde 1984, e que na atualidade encontra-se em sua quarta etapa prevista para ser cumprida no período 1994-1998 (EUROPE ${ }^{3}$, 1995). Embora tendo atingido satisfatoriamente as metas tecnológicas a que se propôs, nem nesta fase descarta-se da pesquisa básica. Os desafios que pretende enfrentar estão no domínio da telemática, do ambiente, da saúde, das ciências do ser vivo, da energia, dos transportes, da divulgação dos resultados, da cooperação internacional, bem como da avaliação do impacto socioeconômico da pesquisa. Todas essas programaçōes deverāo conciliar as necessidades de pesquisa básica com as da aplicada. O que $\varepsilon$ de consenso é que aquela permanece sendo essencial para a Europa. $E$ isso porque, sem a aquisição de conhecimentos que sirvam de alicerces, a inovação tecnologica não poderá ser explorada de maneira plena e satisfatória.

Quero crer que foi, graças a essa orientação que, atualmente, a Comunidade Européia divide com os EUA a produção científica mundial, ultrapassando a deste em alguns casos como clínica médica, química e física (Bourdial ${ }^{1}, 1995$ ).

E nós? O Brasil inclui-se na América Latina que é responsável, segundo a supracitada fonte, por modesto $1,4 \%$ da produção científica do mundo. Apesar disso, damo-nos ao trabalho de realizar levantamentos sobre citaçð̃es de nossa produção e, baseados nessa, divulgamos listas de qualidade. Na verdade, continuamos, como bons colonizados, a importar ciência e tecnologia. Sem falar no enorme contingente cultural que descaracteriza o que poderíamos ter de genuinamente nosso. 
Todavia, a solução é simples ou, como está em moda dizê-lo, encontra-se devidamente "equacionada". Com a palavra os responsáveis pela política científica nacional. Ou então, com a palavra as futuras gerações.

\section{Oswaldo Paulo Forattini}

Editor Científico

\section{Referências Bibliográficas}

1. BOURDIAL, I. Les pays qui font Ia science. Science \& Vie, (930): 30-1, 1995.

2. CESAR, A. Muita incompetência: entrevista com Alberto Santoro. Veja, 28(29): 7-9,1995.

3. ELROPE; dix ans de programmes communautaires. La Recherche (276, suppl), 1995. 